SAARC J. Agri., 12(1), 73-88(2014)

\title{
PREPARATION, QUALITY EVALUATION AND STORAGE STABILITY OF PEACH-SOY FRUIT LEATHER
}

\author{
B. Anju, K. R. Kumari, V. Anand and M. A. Anjum* \\ Division of Post Harvest Technology, Sher-e-Kashmir University of Agricultural \\ Sciences \& Technology, Jammu (J\&K), India
}

\begin{abstract}
The peach-soy leather was prepared from different blends of peach pulp and soy-slurry. The peach pulp and soybean slurry were blended in the ratios of 100:0, 95:5, 90:10, 85:15, 80:20, 75:25 and 70:30. The prepared leather was stored for a period of four months to ascertain changes in physico-chemical and sensory characteristics. The analysis of leather revealed significant differences among different blends. Highest moisture content i.e. 21.99 percent was recorded in B1 (100:0:: P:S). The highest TSS and acidity of 12.05 degree Brix and 2.77 percent were recorded in B1 (100:0:: P:S), respectively, whereas the highest reducing sugar and total sugar contents of 30.16 and 60.41 percent were found in B1 (100:0:: P:S), respectively. The highest protein and fat contents were recorded in B7 (70:30:: P:S), whereas ascorbic acid content was the highest $\left(23.54 \mathrm{mg} 100 \mathrm{~g}^{-1}\right)$ in B7 (70:30:: P:S). Sensory evaluation of leather revealed that the highest score of 8.14 was recorded in B4 (85:15:: P:S) and lowest score of 5.63 was recorded in $\mathrm{B} 7$ (70:30::P:S). In general there was an increase in TSS, acidity and sugars and decrease in protein, fat and ascorbic acid contents and all sensory attributes during four months storage in different blends of leather.
\end{abstract}

Keywords: Peach, Soybean, Leather, Storage, Nutritional Quality

\section{INTRODUCTION}

With the manifold increase in population and wide prevalence of protein malnutrition, attempts are being made to judiciously complement proteins from different conventional sources to overcome this problem. Soybean (Glycine max) being nutritionally very important, is receiving priority in the field of production, as it is a cheap source of good quality protein (40-42\%) and fat (18-20\%). Soybean, rich in lysine amino acid which cereals are devoid of, has made in road in human diet. Peach (Prunus persica L). Batsch is a perishable stone fruit grown extensively in Jammu \& Kashmir. Though the fruit has excellent appearance and quality yet a good source of vitamins, minerals and sugars. Soy foods are one of the fastest growing categories in the Food Industry even as dairy to meat alternatives (Golbitz;

*Corresponding author email: anisaskuast@gmail.com

Received: 07.08.2013 
2000, Tripathi and Mishra; 2005). The soy foods command to be rated as the most common foods in the world as "Healthful Functional Food" in the 21 st Century (Sloan; 2000). So, the protein rich edible products can be prepared by complementing with soybean. Complementation will definitely help in yielding nutritious products at low costs and can significantly contribute in nutritional improvement of our population. Keeping these in view, the present investigation was undertaken to develop the peach-soy blended leather and to evaluate the appropriate blend of peach and soybean which will yield products of acceptable quality. The storage stability was also assessed to see the changes in quality attributes of the products under study.

\section{MATERIALS AND METHODS}

The present investigations were carried out in the Division of Post Harvest Technology, Udheywalla, SKUAST-Jammu during 2007-08. The study was carried out to develop protein enriched leather blended with peach and soy slurry enabling the processing industry to utilize this perishable fruit available in plenty and to assure better returns for the producers.

Extraction of Peach pulp: Ripe and uniform sized fruits of peach free from any kind of blemishes were obtained from the orchards of Division of Fruit Science, Udheywalla, SKUAST-Jammu. The fruits were washed thoroughly in running water to remove adherent foreign material and dust. Peach fruits were dipped in boiling lye solution (2.0 per cent $\mathrm{NaOH}$ ) for five minutes. The fruits were then washed thoroughly under tap water. Subsequently, fruits were dipped in 5.0 per cent citric acid solution for five minutes to neutralize residual alkali from their surface and thereafter, washed in running water to remove the traces of acid. Peach fruits were cut into 4 to 6 pieces. Peach pulp was prepared by hot method as suggested by Lal and Chauhan, 1995 by adding water $\left(100 \mathrm{ml} \mathrm{kg}^{-1}\right.$ of fruit), steam pressured for 5-7 minutes and passed through a pulper. Extracted pulp free of stones and skin was filled in Food Grade PET jars after properly mixing with 2000ppm potassium metabisulphite for further use.

\section{Preparation of Soy slurry}

Soybean used in this study was procured from the local market of Jammu. Soybeans were soaked in water over night, spread on trays for sprouting and water was sprinkled over beans every day. Within three days soybeans sprouted which were then dried and ground into flour.

Soy slurry: Soya slurry was prepared by mixing soy flour to water $(1: 5 \mathrm{w} / \mathrm{v})$ in a blender, followed by heating to boiling $(5 \mathrm{~min})$ and passing through a pulper (Chauhan et al., 1993).

\section{Development of Peach-soy fruit leather}

For fruit leather preparation, peach pulp and soy slurry in different ratios as given below were taken. Peach pulp alone served as a control. 
Peach-soy fruit leather was then analysed for different physico-chemical characters as per treatment details: B1 (100:0), B2 (95:05), B3 (90:10), B4 (85:15), B5 (80:20), B6 $(75: 25)$ and B7 (70:30). The TSS of different mixtures was raised to $30^{\circ} \mathrm{B}$ by addition of sugar and then spreaded over aluminium trays smeared with edible fat $(G h e e)$ and dried in a mechanical dehydrator $\left(60 \pm 2^{\circ} \mathrm{C}\right)$ for about $2 \mathrm{hrs}$ for each layer. Five layers were dried one over the other in the respective trays taking each time $200 \mathrm{ml}$ of the mixture spread over an area of $12 \times 8 \mathrm{inch}^{2}$. The final dried product was packed in 200 gauge polyethylene bags and kept for analysis during subsequent storage period. The acceptable treatment combinations of peach-soy fruit leather, evaluated on the basis of sensory evaluation scores (Hedonic scale) were stored for a period of 4 months at room temperature and analyzed for physico-chemical changes and sensory characteristics at interval of 2 months.

Physical parameters like fruit length, diameters, weight, volume, specific gravity and moisture was determined. Total soluble solids, titratable acidity, sugars (reducing and total), ascorbic acid crude protein and crude fat were estimated by following standard methods. Total soluble solids $\left({ }^{\circ} \mathrm{B}\right)$ were recorded with Hand refractometer (In case of leather 1: 7 dilutions were done using distilled water and the results were interpreted as such).Different chemical parameters viz. total titratable acidity which is expressed as per cent malic acid, ascorbic acid content $\left(\mathrm{mg} 100 \mathrm{~g}^{-1}\right)$, crude proteins and crude fat were determined by following standard procedures as reported by Rangana 1996. The recorded data were subjected to statistical analysis by adopting Completely Randomized Design (CRD).

\section{RESULTS AND DISCUSSION}

The data pertaining to physico-chemical characteristics is highlighted in table 1.As is evident from the same table that the peach fruit had the average fruit weight of $56.20 \mathrm{~g}$, whereas, the average size of fruit as indicated by length and diameter was recorded as 5.03 and $4.62 \mathrm{~cm}$ respectively. The specific gravity and pulp/ stone ratio was found to be 0.96 and 9.18 respectively. These findings were in conformity with the findings of Josan and Chohan (1982), Chander and Khajuria (1983), Colaric et al. (2004). The values for mean moisture content, total soluble solids and titratable acidity of fresh fruit of peach and its pulp were recorded as 86.0 and 88.0 percent; $12{ }^{\circ} \mathrm{B}$ and $11^{\circ} \mathrm{B}$; and 0.86 and 0.60 per cent respectively. Crude protein in peach fruit and peach pulp was found to be 1.20 and 1.00 per cent whereas, per cent fat for the same were recorded as 0.3 and 0.2 respectively. Reducing and total sugars for both the samples were calculated as 3.42 and 8.28 per cent and 3.08 and 7.74 percent, while ascorbic acid was found to be 6.2 and $5.6 \mathrm{mg} 100 \mathrm{~g}^{-1}$ respectively. The similar results have been reported by Josan and Chohan (1982), Chander and Khajuria (1983), Colaric et al. (2004) and Joshi and Bhutani (2005) in peach fruit.

A critical look at data in table 2 revealed that the soy-slurry recorded 86.34 per cent moisture, $6^{\circ} \mathrm{B}$ TSS, 7.5 per cent protein and 3.45 per cent fat. Similar results were obtained by Chauhan et al. (1993). 


\section{Physico-chemical characteristics}

The highest moisture content of 21.99 per cent was recorded in control (B1), while the lowest of 17.50 percent was recorded in peach-soy leather of 70: 30 ratios (B7). The data (Table-3) revealed that by increasing the amount of soy product in peach pulp, the moisture content decreased due the coarser texture of the flour, more ever the increase in soy content in leather decreases the fiber content of leather and in turn the moisture retaining capacity. Generally, processing conditions can affect the amount of water that can be absorbed; these conditions can be varied to influence how tightly the water is bound by the protein in the finished food product (Endres, 2001). Similar results have been reported by Mir (1990) in soy protein concentrate fortified mango bars. These finding are also similar to the findings of Sharma (1997) in leather prepared from different blends of plum-soy and of Thakur (1997) in leather prepared from different blend of apricot-soy. This gives credence to the present study.

The highest TSS content of $12.050 \mathrm{~B}$ was recorded in control (B1) and the lowest of $11.44^{\circ} \mathrm{B}$ in peach-soy leather of $70: 30$ ratios (B7). The decreasing trend in TSS content might be due to the fortification of soy-slurry with peach-pulp. Kaushal and Bhat (1999) also reported similar results in fruit leather blended with sprouted soy-slurry.

Acidity was the highest in control (B1) i.e 2.77 per cent and the lowest in peach-soy leather of 70:30 ratios (B7) i.e 1.95 percent. The study shows that as the content of soy-slurry in peach pulp increased, the titratable acidity decreased significantly due to dilution of acidic factor of the fruit with the addition of the flour and similar observation have been reported by Chauhan et al. (1993) and Kaushal and Bhat (1999).The results of the present study is in line.

The highest reducing and total sugar contents of 30.16 and 60.41 per cent was recorded in control (B1) and the lowest of 27.50 and 55.53 percent in peach-soy leather of 70:30 ratio (B7), respectively. The data revealed that there is a decrease in sugar percentage with the increase in soy-slurry in the blends. Kaushal and Bhat (1999) also reported decrease in sugars in fruit leathers blended with sprouted soyslurry. Total, reducing and non-reducing sugars probably decrease due to inversion of sugars to monosaccharides by acid hydrolysis (Aruna Muralkrishhna et al., 1969).

In case of crude protein, the highest protein content of 3.40 per cent was obtained in peach-soy leather of 70:30 ratios (B7) and the lowest of 1.28 per cent in control (B1). Further in case of fat content, the highest fat content of 1.75 per cent was recorded in peach-soy leather of 70:30 ratios and the lowest of 0.51 per cent in control (B1). The blended product obtained from peach pulp and soy-slurry showed an increase in protein and fat content and this increase is due high protein and fat content of the soy slurry. Mir (1990) also reported an increase in protein and fat contents of mango bars fortified with soy protein concentrate. Sharma (1997) also reported similar results in plum-soy leather. 
As the content of sprouted soy-slurry in peach pulp increased, the ascorbic acid content increased significantly. The highest ascorbic acid content of $23.54 \mathrm{mg}$ $100 \mathrm{~g}^{-1}$ was found in peach-soy leather of 70:30 ratios (B7) and the lowest content of

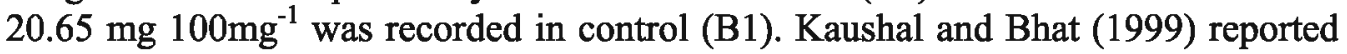
increase in ascorbic acid content of sprouted soy-slurry fortified fruit bars.

\section{Sensory evaluation}

In the sensory evaluation, the highest score of 8.33 for colour was recorded in B4 (85:15 ratio) of peach-soy leather which was at par with B3 (90:10 ratio) of peach-soy leather having scores of 8.00 , while the lowest score of 5.83 was recorded in peach pulp and soy-slurry leather of 70:30 ratio (B6) which was at par with B6 (75:25 ratio) and B5 (80:20 ratio) having scores of 6.17 and 6.00 respectively.

The highest scores of 8.00 for 85:15 ratio of peach-soy leather (B4) have been recorded for texture which was at par with 95:5 ratio of peach-soy leather (B2) having scores 7.42 and the lowest scores of 5.55 was recorded in peach-soy leather of 70:30 ratio (B7) which was at par with B6 (75:25 ratio) having scores of 6.08. The highest score in 85:15 ratio of peach-soy leather might be attributed to a better consistency of the blend. Similar results have been reported earlier by Kaushal and Bhat (1999).

Maximum score of 8.08 was recorded in 85:15 ratio of peach-soy leather (B4) for flavour and the lowest of 5.86 was recorded in 70:30 ratio (B7) which was at par with B6 (95:25 ratio) and B5 (80:20 ratio) having scores of 5.83 and 6.17 respectively. The highest score for $\mathrm{B} 4$ ( $85: 15$ ratio) might be assigned to a balanced proportion of peach and soy in the blend, thereby enhancing the flavour.

The highest score of 8.14 was recorded in peach-soy leather of $85: 15$ ratio (B4) for overall acceptability and the lowest score of 5.63 in peach pulp and soyslurry leather of 70:30 ratio (B7) which was statistically at par with B6 (75:25 ratio) having scores of 6.03 . The reason could be assigned to the fact that leather prepared from 85:15 ratio of peach pulp and soy-slurry had a better consistency and flavour due to an ideal ratio of the blend. Similar findings have been reported by Kaushal and Bhat (1999) and Chauhan et al. (1993).

\section{STORAGE CHANGES IN PEACH-SOY LEATHER}

\section{Physico-chemical characteristics}

The moisture content of peach-soy leather increased during the storage period. The highest moisture content of 25.21 per cent was recorded in control (B1) and the lowest of 20.66 per cent in peach-soy leather of 70:30 ratios (B7) after 4 months of storage period. The increase in moisture content during storage was also reported by Mir and Nath (1993). The increase in moisture content was due to high humidity and temperature in the external environment. The product might have absorbed moisture from the external environment or the change may be due to chemical changes such as browning reactions. 
Total soluble solids of peach-soy leather increased significantly during the storage period. The highest TSS content of $12.94 \mathrm{OB}$ was recorded in control (B1) after 4 months of storage and the lowest of $11.750 \mathrm{~B}$ in peach-soy leather of 70:30 ratio (B7) after 4 months of storage. The increase in TSS during storage was also reported by Sharma (1997), Thakur (1997), Attri et al. (1998), Panday and Singh (1998) and Narayana et al (2002). This increase in TSS during storage might be due to conversion of insoluble polysaccharides into sugars.

In case of acidity, the interaction between blends and storage period were non-significant. The blends registered an increase in acidity during 4 months of storage. The highest acidity of 2.77 per cent was found in control (B1), which increased to 3.06 per cent after 4 months of storage period, while the lowest acidity of 1.95 per cent was recorded in peach-soy leather of 70:30 ratios (B7) which increased to 2.22 per cent after 4 months of storage period. Mir and Nath (1993) found a significant increase in acidity during storage period in fortified mango bars. Similar results have also been reported in mango sheets (Rao and Roy, 1980). Sharma (1997) and Thakur (1997) reported similar results in fortified plum bars and fortified apricot bars respectively. The increase in acidity during storage could be ascribed to the formation of sulphurous acid from sulphur dioxide.

The highest protein content of 3.49 per cent was recorded in peach-soy leather of 70:30 ratio (B7) at 0 storage, which decreased to 3.04 per cent after 4 months of storage and the lowest protein content of 1.28 per cent was recorded in control (B1) at 0 storage, which decreased to 0.98 per cent after 4 months of storage. The decrease in protein content during storage might be due to participation of proteins in Maillard reaction (Cheftel et al., 1985). Similar results have also been reported by Sharma (1997) and Thakur (1997).

During storage, there was decrease in fat content and the interaction between blends and storage period was non-significant. The highest fat content of 1.75 per cent was recorded in peach-soy leather of 70:30 ratios (B7) after preparation which decreased to 1.54 per cent after 4 months of storage, while the lowest fat content of 0.51 per cent was recorded in control (B1), which decreased to 0.35 per cent after 4 month of storage. Decrease in fat content during storage might be due to oxidation of fat in the presence of moisture (Labuza et al., 1970). Similar results have been reported by Sharma (1997) and Thakur (1997) in soy fortified plum bars and fortified apricot bars respectively.

Ascorbic acid showed a decreasing trend in all the blends over a storage period of 4 months at ambient conditions. The highest value of ascorbic acid (23.54 $\mathrm{mg} 100 \mathrm{~g}^{-1}$ ) was recorded in peach-soy leather of $70: 30$ ratios (B7), which was decreased to $16.81 \mathrm{mg} 100 \mathrm{~g}^{-1}$ after 4 months of storage, while the lowest value of ascorbic acid (20.65 mg 100 $\left.\mathrm{g}^{-1}\right)$ was found in control (B1), which decreased to 13.82 $\mathrm{mg} 100 \mathrm{~g}^{-1}$ after 4 month of storage. The decreasing trend in ascorbic acid during storage has also been reported by Sharma (1997), Thakur (1997), Attri et al. (1998). This decrease in ascorbic acid during storage was due to its oxidation. 
All the blends showed a significant increase in reducing sugars from a mean value of 28.68 per cent at 0 month to 30.91 per cent after 4 months. The increase in reducing sugars during storage might be due to hydrolysis or break down of starch into sugars (Will et al, 1983). A significant increase in reducing sugars was observed in mango sheets by Rao and Roy (1980), in fortified mango bars by Mir and Nath. (1993), in fortified plum bars by Sharma (1997) and in fortified apricot bars by Thakur (1997).

A significantly highest and lowest mean total sugar content of 61.48 and 56.67 per cent was recorded for B1 and B7. During storage, the total sugars increased from 57.58 to 59.80 per cent over a period of 4 months. These findings are in consonance with the findings of Sharma (1997), Thakur (1997), Attri et al. (1998), Hemakar et al. (2000) and Narayana et al. (2002). The increase in total sugars was apparently due to hydrolysis of starch and conversion of non-reducing sugars into reducing sugars during storage as found by Roy and Singh (1979) in bael fruit products and by Ragab (1987) in apricot Jam.

Sensory evaluation score for colour showed a decreasing trend from 6.89 at 0 month to 6.29 after 4 months of storage. This decrease in appeal for colour was probably due to browning reactions occurring in the product. The highest mean score of 8.15 was recorded in B4 (85:15 ratio) and the lowest of 5.13 in B7 (70:30 ratio).

In case of texture mean score of $6.76,6.43$ and 6.07 at 0,2 and 4 months of storage respectively indicated decrease in appeal for texture of peach-soy leather with the increase in storage period. A significantly higher appeal for texture was recorded in $\mathrm{B} 4$ (85:15 ratio) of peach-soy leather at all the storage intervals, while the lowest appeal for texture was observed for $B 7$ (70:30 ratio).

The mean score for flavour decreased from 6.69 to 6.12 after 4 months of storage which might be attributed to various chemical changes and loss of volatiles. Moreover, B4 (85:15 ratio) showed the highest mean score of 7.76 for flavour during 4 months of storage where as B7 (70:30 ratio) showed the lowest mean score of 5.08, which was probably due to higher proportion of soy flour in the leather.

Overall acceptability of the peach-soy leather showed a reduction in the mean score from 6.81 to 6.16 after 4 months of storage period. Mir and Nath (1993) also reported a decrease in sensory scores of soy fortified mango bars during 6 months of storage. The peach pulp and soy-slurry leather of 85:15 ratios recorded the maximum scores for overall acceptability and was adjudged as the best blend and the leather of this blend was liked much due to its colour and flavour.

\section{CONCLUSION}

The control i.e. unfortified peach leathers recorded the highest TSS and per cent moisture, titratable acidity, reducing sugar and total sugar as compared to soyslurry blended peach leather, whereas blended leather was rich in protein and fat 
contents. Peach pulp and soy-slurry leather of 70:30 ratio recorded maximum protein, fat and ascorbic acid contents. The various blends of peach-soy leather exhibited an increase in moisture, TSS, titratable acidity and sugars but decrease in protein, fat, ascorbic acid contents and all the sensory attributes during four months storage at room temperature.

However, on the basis of sensory evaluation, peach pulp and soy-slurry leather of 85:15 ratio was found to be the best among different blends when compared at zero storage as well as after four months storage.

From the present studies, it can be concluded that peach fruit can be blending with soybean up to 15 per cent to yield nutritious value added product. Such products can be kept for longer duration without adversely affecting their physicochemical and sensory characteristics. Thus, by preparing fortified peach fruit products, the processing industry can fulfill the dual purpose of better use of this fruit and higher returns to the growers successfully.

\section{REFERENCES}

A.O.A.C. 1985. Official Methods of Analysis, Association of official Analytical Chemists, Hortwitz, W. (Ed). 14th ed. Washington D.C., U.S.A

A.O.A.C. 1994. Official Methods of Analysis, Association of Official Analytical Chemists, Washington, D.C. 15th edn.

Aruna, K., Dhanalakshmi, R., and Vimala, V. 1998. "Development and storage stability of Cereal-based papaya powder". Journal of Food Science and Technology, 35 (3):250-254

Attri, B.L., Lal, B.B. and Joshi, V.K. 1998. Physico-chemical characteristics, sensory quality and storage behavior of sandy pear juice blended with temperate fruit juice/pulps. Indian food packer, 52(6): 36-42

Chander, S. and Khajuria, H.N. 1983. Studies on the maturity standards of subtropical peach Cv. Flordasun. Punjab journal of horticulture, 23(3-4): 168171

Chauhan, S.K., Joshi, V.K. and Lal, B.B. 1993. Apricot-Soy fruit-bar: A new protein enriched product. Journal of food science and technology, 30(6):457-458

Colaric, M., Stampar, F. and Hudina, M. 2004. Contents of sugars and organic acids in the cultivars of peach (Prunus persica L.) and nectarine (Prunus persica var. nucipersica Schneid.). Acta agriculturae slovenica, 83-1

Endres, J.G. 2001. Soy Protein Products: Characteristics, nutritional aspects, and utilization. AOCS Press, Champaign, IL, USA

Golbitz, P. 2000. Soy foods: State of industry and market. Presented at soy foods 2000. Ortando. Pa. Feb. 16-18 
Hemakar, A.K., Tomar, M.C. and Singh, U.B. 2000. Studies on blending of guava pulp with mango pulp for dehydration (mango-guava sheet). Indian food packer, 54(4): 45-50

Josan, J.S. and Chohan, G.S. 1982. Studies on maturity standards of peach Cv. Flordasun. Haryana journal of horticulture science, 11(1-2): 1-4

Joshi, V.K. and Bhutani, V.P. 2005. Peach and nectarine. In: handbook of fruit science and technology, production, composition, storage and processing (Eds. D.K.Salunkhe and S.S.Kadam). Marcel Dekker, Inc. NewYork, p 243296

Kalra, S.K, Tandon, D.K, and Singh, B.P. 1991, Evaluation of mango-papaya blended beverage. Indian food packer, 45(1): 33-36

Koushal, B.B. Lal. and Bhat, Anju. 1999. Studies on physico-chemical properties of fruit leather blended with sprouted soya slurry. Indian food packer, (9\&10): $18-23$

Labuza,T.P., Tannenbum, S.R. and Karel, M. 1970. Water content and stability of low moisture and intermediate moisture foods. Food technology, 20:38-42

Lal, B.B. and Chauhan, S. K. 1995. Technology and development of soy stone fruit products. Annual progress report (1995). Submitted to ICAR, Adhoc research scheme, New Delhi

Mir, M. A.1990. Development and evaluation of fortified mango bars. Ph.D. Thesis. G. B. Pant University of Agriculture and Technology, Pantnagar, India

Mir, M. A and Nath, Nirankar. 1993. Storage changes in fortified mango bars. Journal of food science and technology, 30(4): $279-282$

Narayana, C.K., Sathiamoorthy, S. and Mary, A.E. 2002. Studies on ready-to-serve beverage from enzyme clarified banana juice. Progressive Horticulture, 34(1): 65-71

Pandey, A.K. and Singh, I.S. 1998. Studies on preparation and preservation of guava ready-to-eat beverage. Indian journal of horticulture, 56(2): 130-132

Ragab, M. 1987. Characteristics of apricot jam sweetened with saccharin and xylitol. Food Chemistry, 23: 55-64

Rangana, S. 1986. Handbook of analysis and quality control for fruit and vegetable products, 2nd Edition, Tata McGraw Hill Publishing Co. Ltd., New Delhi

Rao, V.S. and Roy, S.K. 1980. Studies on dehydration of mango pulp. II Storage of mango leather/sheet. Indian food packer, 34 (3): $72-79$

Sethi, V. 1993. Changes in physico-chemical characteristics of litchi squash during storage at ambient temperature. Indian journal horticulture, 50(4): 327-332 
Sharma, Mala. 1997. Studies on the preparation and evaluation of plum-soy products. M.Sc. Thesis. Dr.Y.S. Parmar Univeristy of Horticulture and Forestry, Nauni, Solan (HP)

Sloan, A.E. 2000. The top ten functional foods trends. Food technology, 54(4): 3362

Thakur, Neena. 1997. Development of Apricot- Soya Products and their quality evaluation. M.Sc. Thesis. Dr.Y.S. Parmar University of Horticulture and Forestry, Nauni, Solan (HP)

Tripathi, A.K. and Mishra, A.K. 2005. Soyabean: a consumate functional food: A review. Journal of food science and technology, 42(2):111-119

Wills, R.B.H., Scriven, F.M. and Greenfield, H. 1983. Nutrient composition of stone fruit (Prunus spp.) cultivars: apricot, cherry, nectarine, peach and plum. Journal of science food and agriculture, 34: 1383

Table 1. Physico-chemical characteristics of peach fruit and pulp

\begin{tabular}{|c|c|c|c|}
\hline \multirow{2}{*}{ Sl. No } & \multirow{2}{*}{ Characteristics } & \multicolumn{2}{|c|}{ Peach } \\
\hline & & Fruit & Pulp \\
\hline 1. & Fruit weight $\quad(\mathrm{g})$ & 56.20 & -- \\
\hline 2. & Fruit diameter $(\mathrm{cm})$ & 4.62 & -- \\
\hline 3. & Fruit length (cm) & 5.03 & -- \\
\hline 4. & Specific gravity & 0.96 & -- \\
\hline 5. & Pulp/ stone ratio & -- & 9.18 \\
\hline 6. & Moisture (\%) & 86.00 & 88.00 \\
\hline 7. & $\operatorname{TSS}\left({ }^{\circ} \mathrm{B}\right)$ & 12.00 & 11.00 \\
\hline 8. & Titrated acidity (\%) & 0.86 & 0.60 \\
\hline 9. & Reducing sugar (\%) & 3.42 & 3.08 \\
\hline 10. & Total sugar (\%) & 8.28 & 7.74 \\
\hline 11. & Crude protein (\%) & 1.20 & 1.00 \\
\hline 12. & Fat $(\%)$ & 0.30 & 0.20 \\
\hline 13. & Ascorbic acid $(\mathrm{mg} / 100 \mathrm{~g})$ & 6.20 & 5.60 \\
\hline
\end{tabular}

Table 2. Physico-chemical characteristics of soybean slurry

\begin{tabular}{clc}
\hline S.No. & Characteristics & Soy-siurry (1:5) \\
\hline 1. & Moisture $(\%)$ & 86.34 \\
2. & TSS $\left({ }^{\circ} \mathrm{B}\right)$ & 6.00 \\
3. & Crude protein $(\%)$ & 7.21 \\
4. & Fat $(\%)$ & 3.45
\end{tabular}




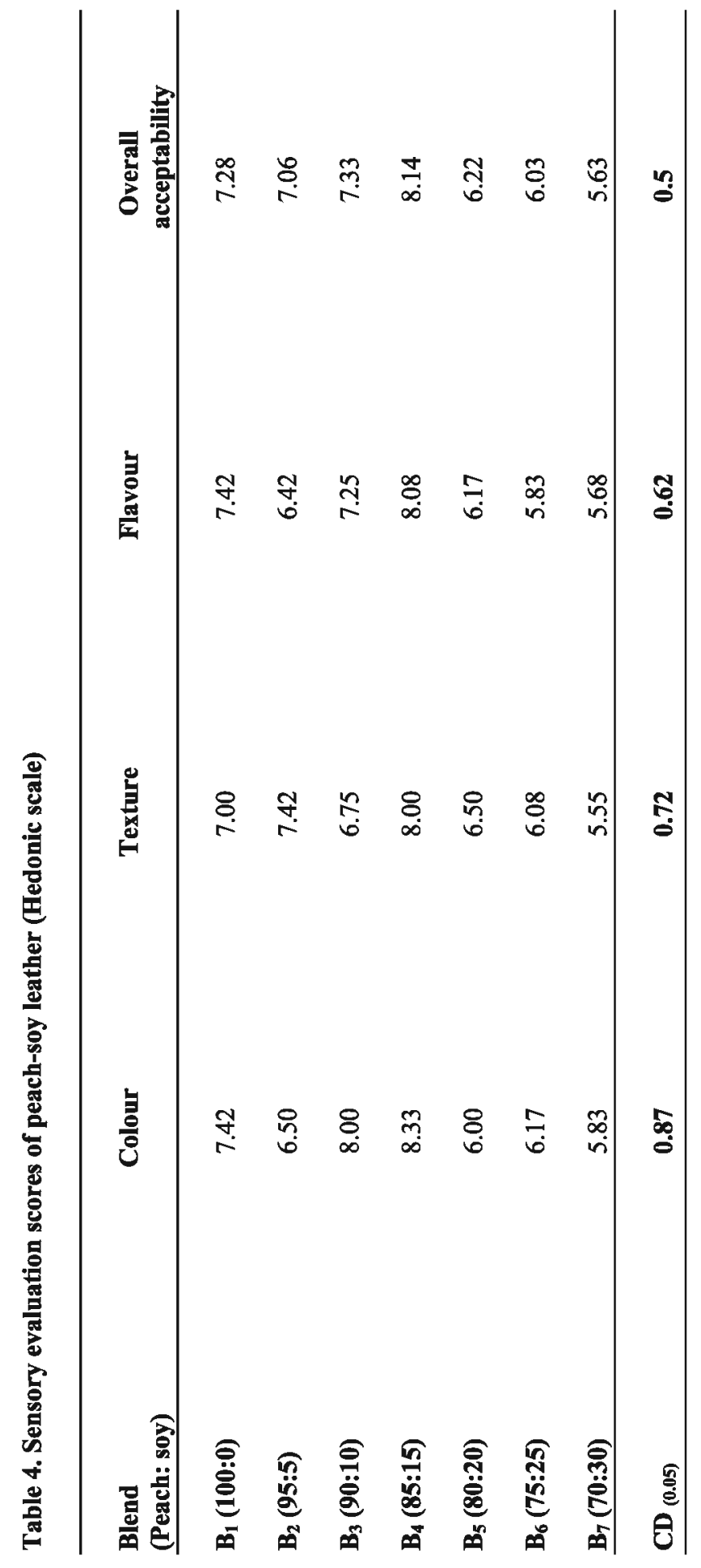




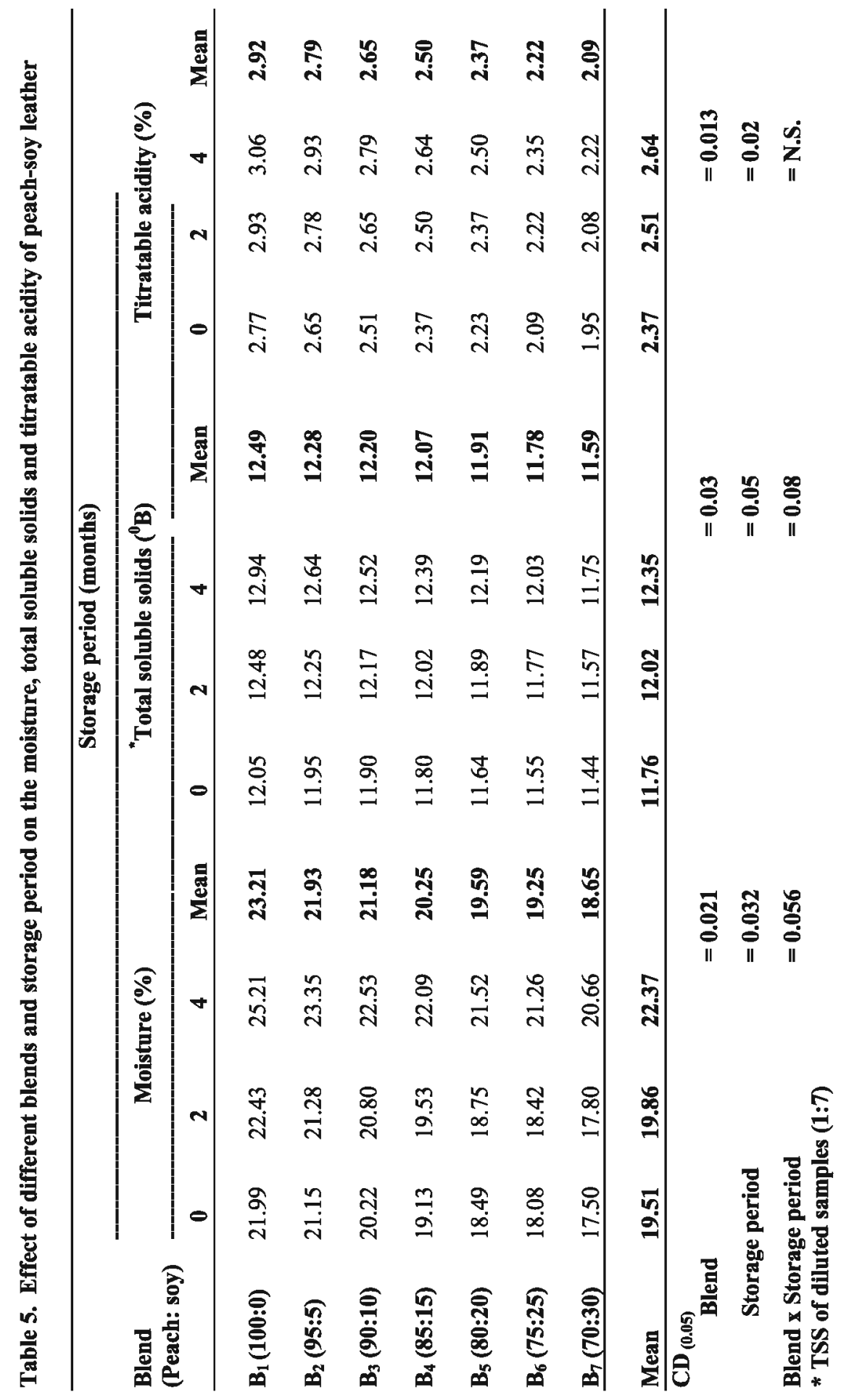




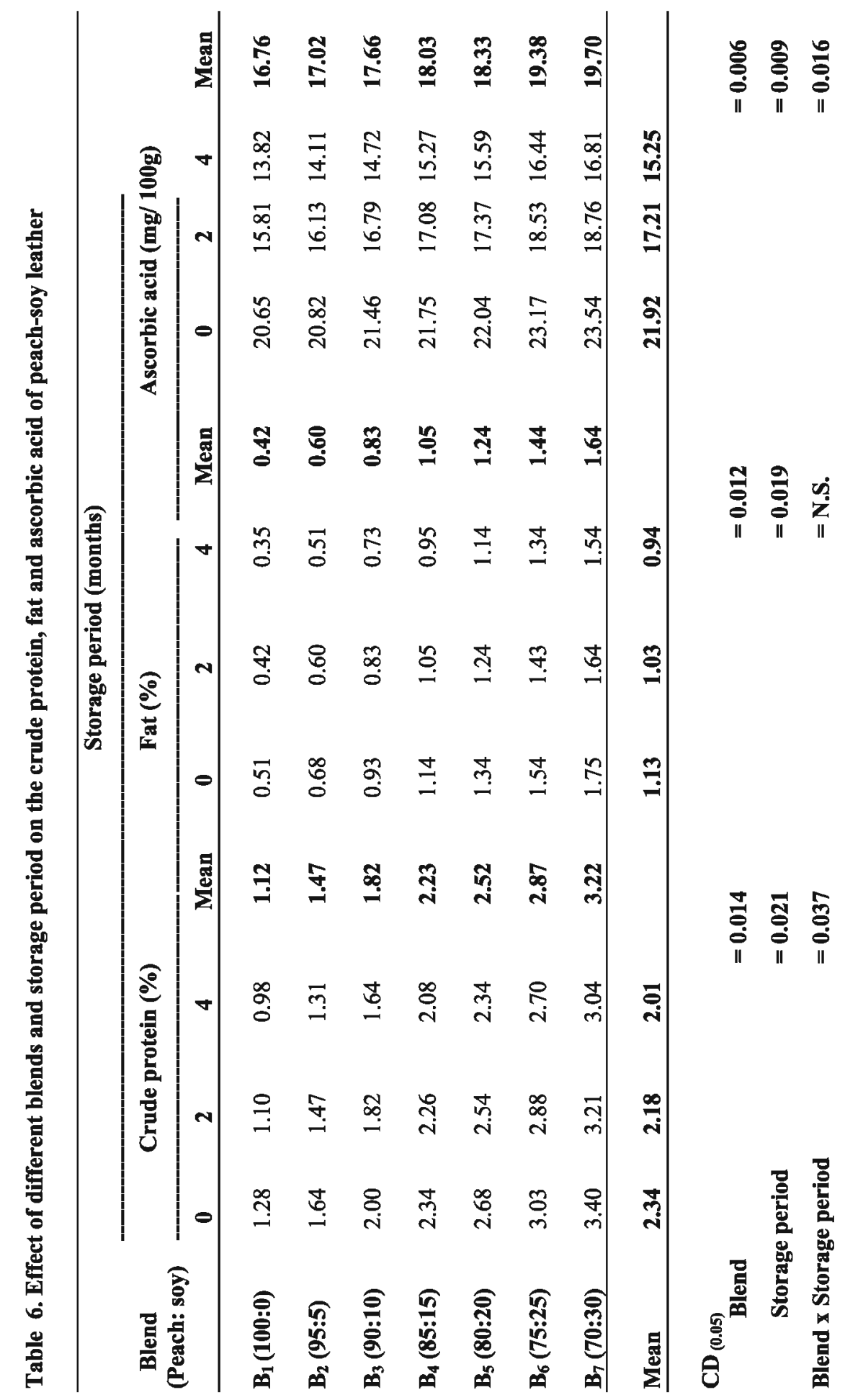




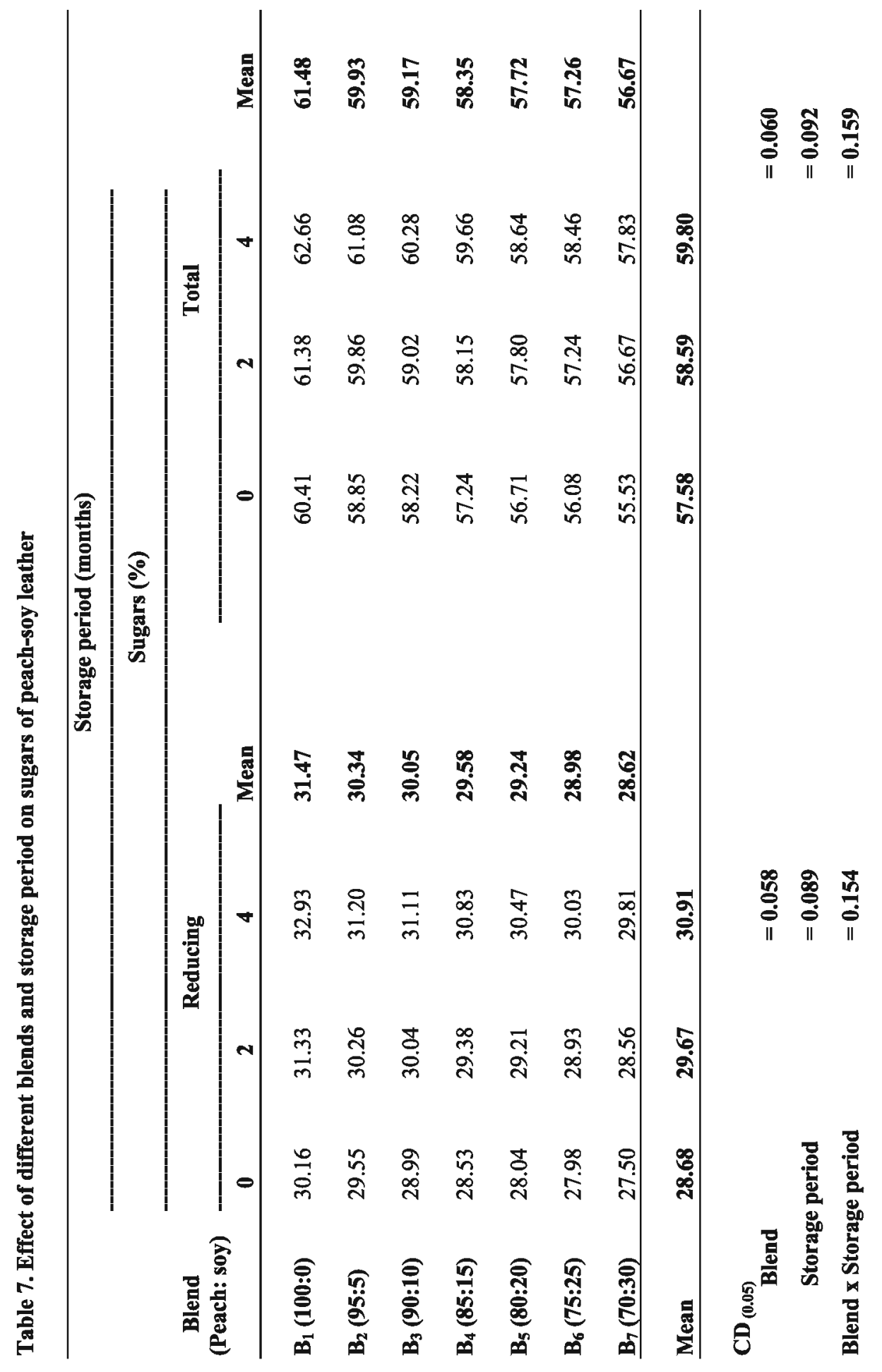




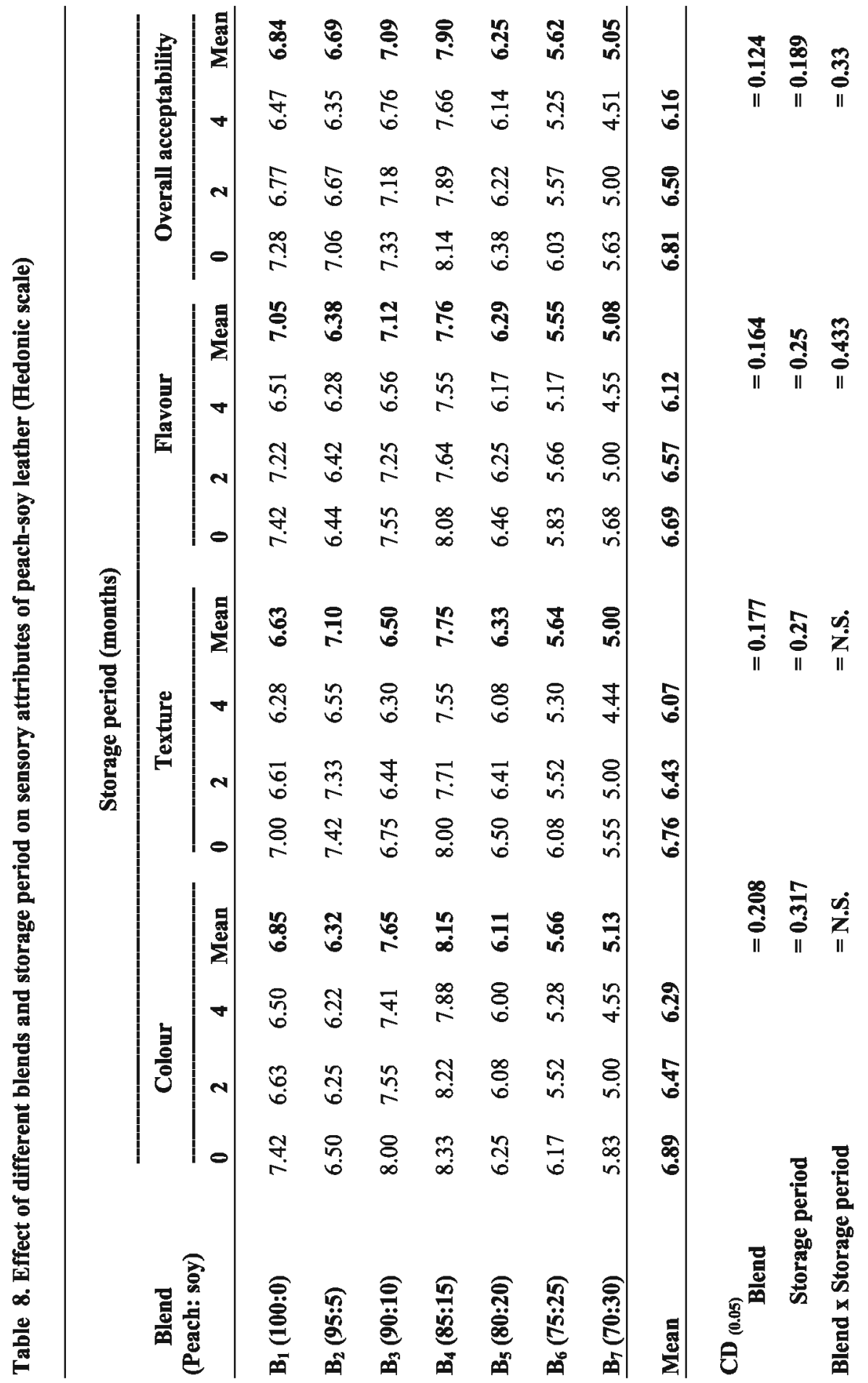




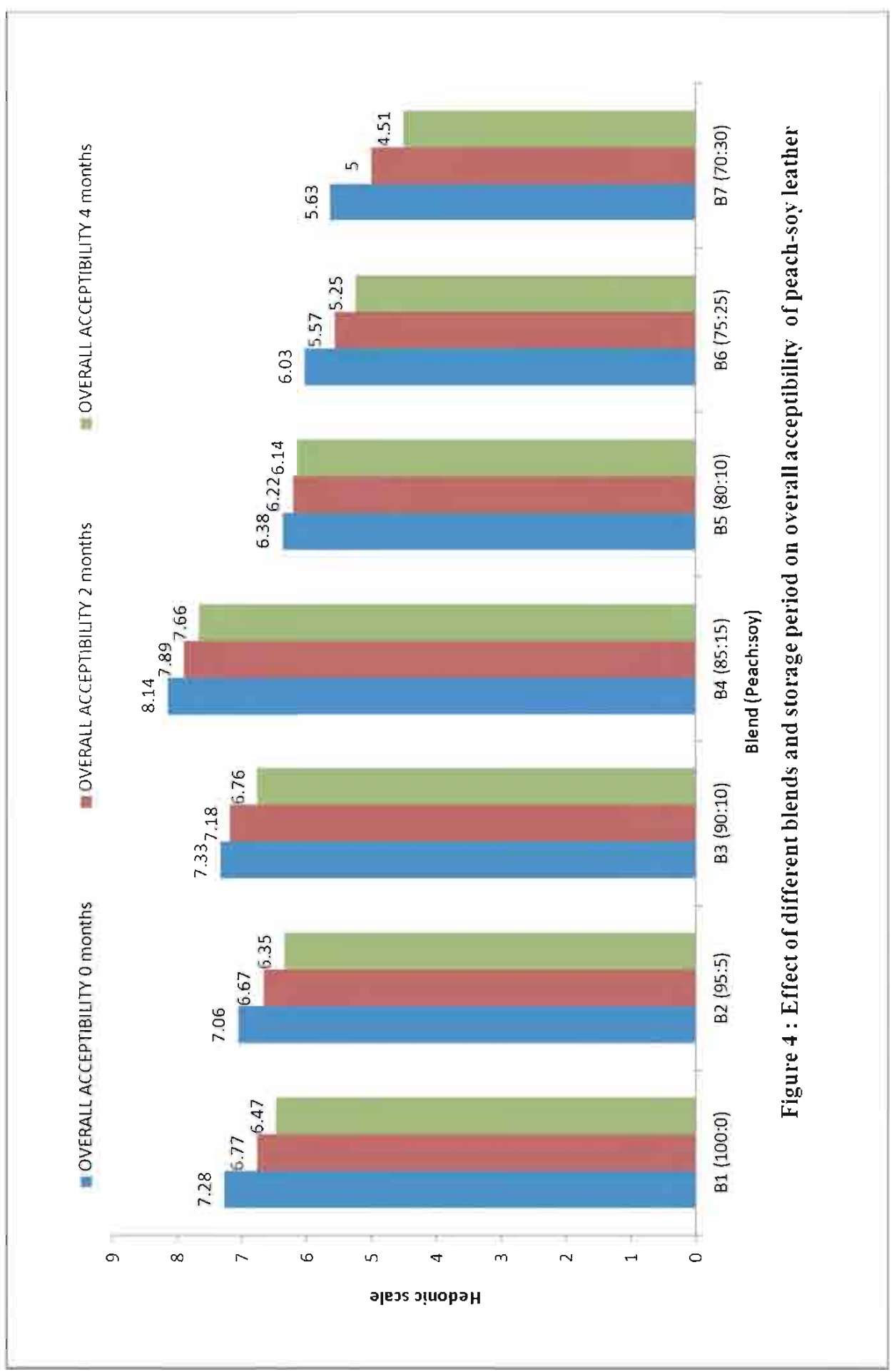

